\title{
Thermal dependence of seagrass ecosystem metabolism in the Red Sea
}

\author{
Celina Burkholz, Carlos M. Duarte, Neus Garcias-Bonet* \\ Red Sea Research Center, King Abdullah University of Science and Technology, Thuwal 23955-6900, Saudi Arabia
}

\begin{abstract}
The Red Sea is one of the warmest seas with shallow seagrass ecosystems exposed to extreme temperatures, in excess of $35^{\circ} \mathrm{C}$, during the summer months. Seagrass meadows are net autotrophic ecosystems, but respiration increases faster than primary production with temperature. This may lead to a shift from an autotrophic to a heterotrophic system at the highest temperatures. Although tropical seagrasses are adapted to high temperatures, the metabolic rates of Red Sea seagrasses have not yet been reported. Here we assessed the community metabolism of 2 seagrass ecosystems, an Enhalus acoroides monospecific meadow and a Cymodocea serrulata and Halodule uninervis mixed meadow, located in the central Red Sea. We measured in situ net community production $(\mathrm{NCP})$, community respiration $(R)$, gross primary production $(\mathrm{GPP})$, activation energy and community production-irradiance curves along their natural temperature gradient over 1 yr by measuring diel fluctuations in dissolved oxygen. The results were species-specific; while the monospecific meadow was autotrophic throughout the year (annual weighted average NCP: $64.63 \pm 11.89 \mathrm{mmol} \mathrm{O}_{2} \mathrm{~m}^{-2} \mathrm{~d}^{-1}$, GPP: $R$ ratio: $1.42 \pm 0.06$ ), the mixed meadow was heterotrophic during the summer months (annual weighted average NCP: $-4.15 \pm 9.39 \mathrm{mmol} \mathrm{O}_{2} \mathrm{~m}^{-2} \mathrm{~d}^{-1}$, GPP: $R: 1.04 \pm 0.05$ ). In both seagrass meadows, $R$ and GPP increased with increasing temperature, but differences in activation energies indicated that the mixed meadow is more sensitive to increasing seawater temperatures. These findings suggest contrasting responses in tropical seagrass species to rising temperature, pointing out the potential vulnerability of seagrasses to ocean warming in the Red Sea.
\end{abstract}

KEY WORDS: Seagrass ecosystems $\cdot$ Community metabolism $\cdot$ Thermal dependence $\cdot$ Activation energy $\cdot$ PI curves $\cdot$ Red Sea

\section{INTRODUCTION}

Seagrass ecosystems rank among the most productive (Duarte \& Chiscano 1999) and economically valuable ecosystems in the world (Costanza et al. 1997), offering important ecosystem services such as nurseries, food and shelter for commercially important fisheries, coastal stabilization, carbon sequestration, removal of nutrients (Orth et al. 2006, Ruiz-Frau et al. 2017) and bacterial pathogens (Lamb et al. 2017) and protection of archaeological heritage (Krause-Jensen et al. 2019). Seagrass ecosystems can

\footnotetext{
${ }^{*}$ Corresponding author: neus.garciasbonet@kaust.edu.sa
}

be found worldwide, except for Antarctica (Green \& Short 2003), and inhabit a broad thermal range (Lee et al. 2007, Pedersen et al. 2016). However, warming can lead to the loss of seagrass meadows and the services they provide, with warming-derived loss of seagrass reported for the western Mediterranean (Díaz-Almela et al. 2009, Marbà \& Duarte 2010), Western Australia (Arias-Ortiz et al. 2018), Florida Bay (Carlson et al. 2018) and Chesapeake Bay (Moore \& Jarvis 2008, Moore et al. 2014).

Due to climate change, the global mean surface temperature has increased since pre-industrial

() The authors 2019. Open Access under Creative Commons by Attribution Licence. Use, distribution and reproduction are unrestricted. Authors and original publication must be credited. 
times and is predicted to increase by $0.3-1.7^{\circ} \mathrm{C}$, under a mitigation scenario (Intergovernmental Panel on Climate Change representative concentration pathway [RCP] 2.6), to $2.6-4.8^{\circ} \mathrm{C}$, under a business-as-usual scenario (RCP 8.5), by the end of the $21^{\text {st }}$ century (Collins et al. 2013). Yet, some seagrass species already live close to or even exceed their thermal limit (York et al. 2013, Pedersen et al. 2016, Collier et al. 2017). Increasing temperatures can negatively affect the productivity of seagrasses (Marsh et al. 1986) and their ecosystem services (Pedersen et al. 2011) as well as their mortality rate (Marbà \& Duarte 2010, Collier \& Waycott 2014). However, these effects vary with different species, their thermal optima and geographical ranges as well as local acclimation and adaptation (Short \& Neckles 1999).

Warming can also have varying effects on the different metabolic rates within a seagrass meadow. Net community production (NCP) and the photosynthesis:respiration $(P: R)$ ratio define the metabolic state of an ecosystem, where a net autotrophic ecosystem is characterized by $\mathrm{NCP}>0$ and $P: R>1$, while a system with $\mathrm{NCP}<0$ and $P: R<1$ is defined as heterotrophic (Duarte et al. 2011). Rising temperatures are known to increase photosynthesis at lower rates than respiration (Harris et al. 2006) up to the system's thermal optimum and to decrease photosynthesis past the optimum temperature (Marsh et al. 1986), potentially leading to a shift from an autotrophic to a heterotrophic system. In a heterotrophic system, the photosynthetically fixed carbon cannot meet the requirements of community respiration, leading to an imbalance between these metabolic rates that requires allochthonous subsidies of organic carbon and leads to these communities acting as $\mathrm{CO}_{2}$ sources and $\mathrm{O}_{2}$ sinks (Duarte et al. 2011).

Globally, seagrass ecosystems tend to be autotrophic systems, with average NCP rates of $27.2 \pm$ $5.8 \mathrm{mmol} \mathrm{O}_{2} \mathrm{~m}^{-2} \mathrm{~d}^{-1}$ (Duarte et al. 2010). Tropical seagrass ecosystems, despite the warmer temperature regimes they experience, also tend to be net autotrophic systems although with lower NCP rates than temperate seagrasses $(23.7 \pm 7.8$ and $33.5 \pm$ $8.0 \mathrm{mmol} \mathrm{O}_{2} \mathrm{~m}^{-2} \mathrm{~d}^{-1}$, respectively, Duarte et al. 2010). Nevertheless, tropical seagrasses are adapted to high temperatures as evidenced by higher optimum temperature $\left(T_{\text {opt }}\right)$ for photosynthesis $\left(35^{\circ} \mathrm{C}\right.$ in Cymodocea serrulata and Halodule uninervis: Adams et al. 2017, Collier et al. 2017; and $32-33^{\circ} \mathrm{C}$ in Thalassia hemprichii and Enhalus acoroides: Pedersen et al. 2016) compared to the $T_{\text {opt }}$ found in tem- perate seagrasses $\left(25^{\circ} \mathrm{C}\right.$ in Zostera marina: Marsh et al. 1986; and $18-23^{\circ} \mathrm{C}$ in Posidonia sinuosa: Masini et al. 1995). However, these studies only display $T_{\text {opt }}$ of single species using leaf pieces or shoots and do not necessarily reflect how temperature affects the entire community or ecosystem. A community might experience different effects, as many organisms (e.g. epiphytes, algae, microbes, plankton), besides the foundation seagrass species, contribute to the community metabolism of a seagrass ecosystem. In situ community measurements can therefore contribute to previous single-species studies, as we can assess the effects on a community level taking into account not only the present seagrass species but also the whole community. Studies on ecosystem metabolism are limited, and the metabolic rates of seagrass ecosystems are especially lacking for the Red Sea.

The Red Sea is a semi-enclosed sea basin supporting high sea surface temperatures (up to $36^{\circ} \mathrm{C}$ ) and rapid warming (Belkin 2009, Chaidez et al. 2017). Thus, seagrass ecosystems in the Red Sea encounter the warmest thermal regimes globally and are likely to be near their upper natural thermal thresholds. The Red Sea therefore provides a unique study site to evaluate the ecological dynamics of tropical seagrasses to better understand how climate change will affect seagrass ecosystems and their performance. Measuring seagrass community production, community respiration and community primary production rates along their annual in situ thermal range will help assess their thermal dependence as well as predict how these ecosystems will cope with future warming. Additionally, the photosynthetic performance of seagrasses is closely related to temperature, temperature changes and irradiance (Bulthuis 1987, Lee et al. 2007) and typically varies between species and seasons, with higher rates at higher temperature (Lee et al. 2007). Community metabolism-irradiance curves can help evaluate seagrass productivity by identifying changes with changing light levels, increasing temperatures, and between species.

In this study, we assessed the net community production, gross primary production, community respiration and community metabolism-irradiance curves of 2 tropical seagrass meadows in the central Red Sea by measuring diel fluctuations in dissolved oxygen using in situ incubation chambers over 1 yr. In addition, we assessed the temperature dependence of seagrass ecosystem metabolism under its natural thermal range in the warm Red Sea. 


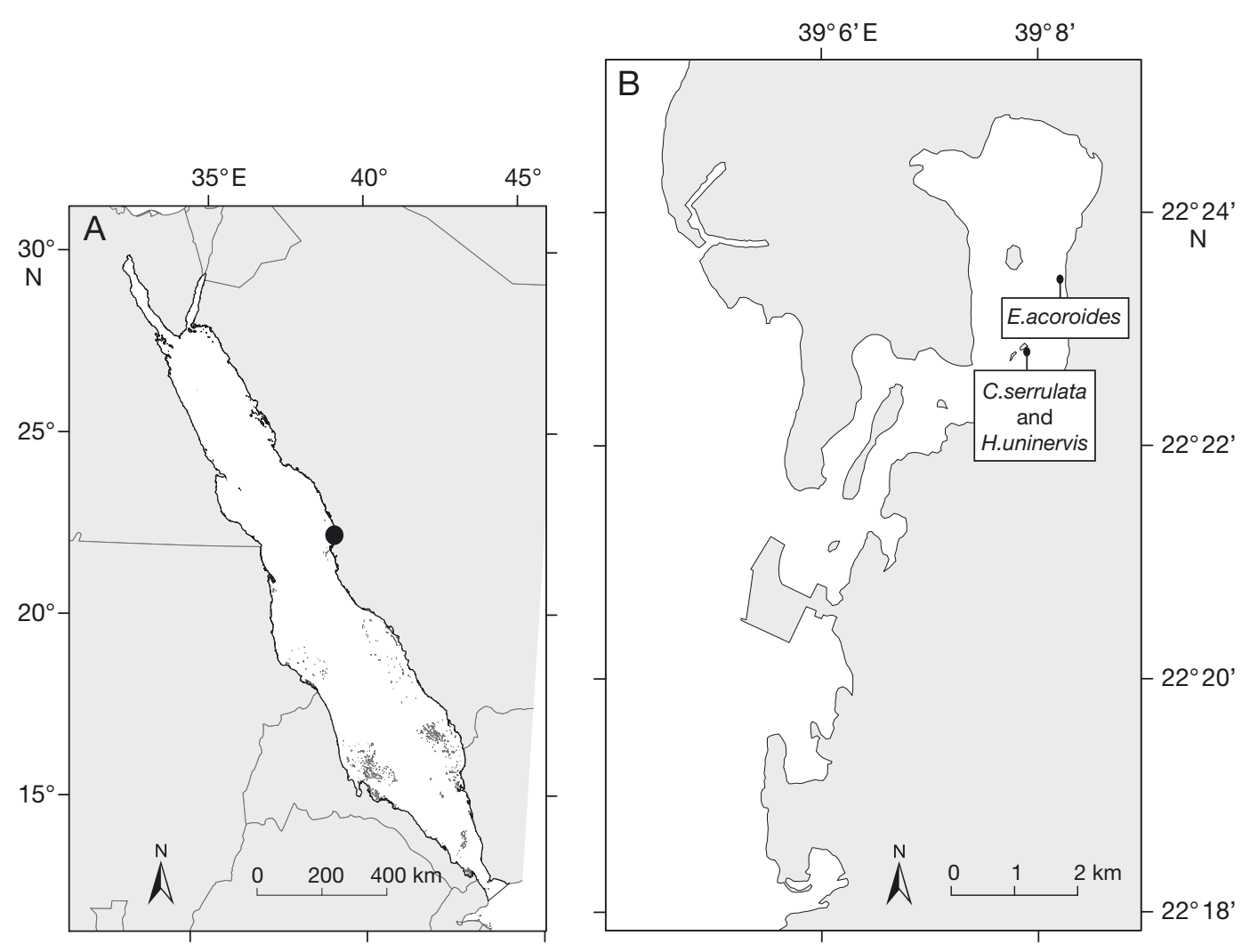

Fig. 1. (A) Location of the study sites in the Red Sea and (B) a closer view of the locations of the monospecific (Enhalus acoroides) and mixed (Cymodocea serrulata and Halodule uninervis) meadows

\section{MATERIALS AND METHODS}

\subsection{Study site}

The study was conducted in a shallow, enclosed coastal lagoon located in the central Red Sea (Fig. 1). We sampled 2 seagrass meadows: a Cymodocea serrulata and Halodule uninervis mixed meadow at $0.7 \mathrm{~m}$ depth $\left(22^{\circ} 22^{\prime} 50.40^{\prime \prime} \mathrm{N}, 39^{\circ} 7^{\prime} 54.50^{\prime \prime} \mathrm{E}\right)$ and an Enhalus acoroides monospecific meadow at $2.0 \mathrm{~m}$ depth $\left(22^{\circ} 23^{\prime} 23.2^{\prime \prime} \mathrm{N}, 39^{\circ} 08^{\prime} 08.0^{\prime \prime} \mathrm{E}\right)$. Hereafter, we refer to these 2 meadows as mixed and monospecific meadows, respectively, acknowledging that we studied the whole community response, taking into account the metabolism of many other organisms present in this community besides the foundation seagrass species. We estimated in situ metabolic rates of the seagrass community in both sites from June 2016 to April 2017. We conducted 9 and 6 samplings (covering 7 and $6 \mathrm{mo}$ ) in the mixed meadow and the monospecific meadow, respectively. During summer, we increased the sampling effort to capture the warmest period, especially in the shallow mixed meadow. Each sampling consisted of 2 consecutive days of fieldwork during which we deployed incubation chambers.

\subsection{Field setup}

At each sampling, we randomly deployed 4 replicate incubation chambers containing sediment and seagrass shoots in both meadows. The incubation chambers consisted of a plastic cylindrical core (mixed meadow: $26 \mathrm{~cm}$ length and $9.5 \mathrm{~cm}$ diameter, monospecific meadow: $40 \mathrm{~cm}$ length and $9.5 \mathrm{~cm}$ diameter) that was carefully pushed into the sediment and a plastic bag (mixed meadow: $40 \mathrm{~cm}$ length, monospecific meadow: $80 \mathrm{~cm}$ length) that was firmly attached to the plastic core with rubber bands and plastic ties. The plastic bag was built with a transparent coextruded multilayer film highly impermeable to oxygen (Multifol GVA 180, Südpack). The flexibility of the plastic film allowed the movement of the plastic bag with wave and tidal movements. Because of the enclosed nature of the lagoon (Fig. 1B), tidal currents were strong in the 2 locations and provided, in interacting with the flexible walls, mixing of the seawater enclosed in the 
chamber. After deployment, the length of the core and bag above the ground were recorded to calculate the total volume of each chamber. Inside each chamber, we deployed a dissolved oxygen and temperature logger (miniDOT, Precision Measurements Engineering) recording every $10 \mathrm{~min}$ for $24 \mathrm{~h}$. The miniDOT loggers were attached to a stainless steel bar that was previously fixed in the center of the plastic core, preventing damage to seagrass rhizomes and roots. In each meadow, we also deployed an Odyssey logger (Dataflow Systems) within the canopy to record photosynthetically active radiation (PAR) in 1 of the 4 replicate chambers. In addition, we monitored and recorded the seawater temperature, dissolved oxygen and PAR outside the chambers for the same $24 \mathrm{~h}$ periods by deploying another dissolved oxygen and temperature logger (miniDOT, Precision Measurements Engineering), an EXO1 multiparameter sonde (Xylem) and an Odyssey PAR logger (Dataflow Systems) within the seagrass meadow but outside the chambers. Annual (mean \pm $\mathrm{SE}$ ) minimum oxygen values were $3.7 \pm 0.5$ and $5.9 \pm$ $0.2 \mathrm{mg} \mathrm{O}_{2} \mathrm{l}^{-1}$ inside the incubation chambers and $5.0 \pm$ 0.2 and $3.2 \pm 0.8 \mathrm{mg} \mathrm{O}_{2} \mathrm{l}^{-1}$ outside the chambers in the mixed and monospecific meadows, respectively. Annual (mean $\pm \mathrm{SE}$ ) maximum oxygen values were $10.7 \pm 0.3$ and $11.0 \pm 0.4 \mathrm{mg} \mathrm{O}_{2} \mathrm{l}^{-1}$ inside the incubation chambers and $6.6 \pm 0.2$ and $7.6 \pm 0.5 \mathrm{mg} \mathrm{O}_{2} \mathrm{l}^{-1}$ outside the incubation chambers in the mixed and monospecific meadows, respectively.

At the end of the $24 \mathrm{~h}$ incubations, the chambers were opened by detaching the plastic bags but keeping the plastic core at the base. Then, the sediment and seagrass shoots were collected using the same cylindrical plastic core by carefully pulling the core up to avoid disruption of the sediment structure. The cores were then transported to the laboratory, where the shoots and rhizomes were dried at $60^{\circ} \mathrm{C}$ to a constant dry weight (DW) to record the plant biomass in each core.

\subsection{Net community production, respiration and gross primary production}

NCP was calculated by the difference between the initial and final dissolved oxygen concentration in the $24 \mathrm{~h}$ incubations. The community respiration $(R)$ rate was calculated from the slope of the linear decrease in dissolved oxygen concentration during night, when PAR $=0 \mu \mathrm{mol}$ photons $\mathrm{m}^{-2} \mathrm{~s}^{-1}$, and then converted into daily rates. The community gross primary production (GPP) was estimated according to Duarte et al. (2010) as follows:

$$
\mathrm{GPP}=\mathrm{NCP}-R
$$

The rates were converted to an aerial base taking into account the core surface area and the total volume of the incubation chamber and standardized by seagrass biomass taking into account the plant biomass (DW) in each chamber.

\subsection{Activation energy}

We assessed the thermal dependence of seagrass community GPP and $R$ rates by fitting the Arrhenius function. We estimated the activation energy, derived from the relationship between the natural logarithm of GPP and $R$ rates and the inverse temperature multiplied by the Boltzmann constant. The activation energy is the slope of the Boltzmann factor or the Arrhenius equation (Brown et al. 2004, Dell et al. 2011, Marbà et al. 2015):

$$
\ln (V)=C+\left[E \times\left(\frac{1}{k T}\right)\right]
$$

where $V$ is the value of the metabolic rate, $C$ is the intercept of the fitted regression equation, $E$ is the activation energy, $k$ is the Boltzmann constant and $T$ is the temperature (in K). The activation energy provides useful ecological information on the thermal dependence of a given metabolic process (Dell et al. 2011).

\subsection{Community production-irradiance curves}

Community production-irradiance (PI) curves were estimated for both meadows and each sampled month. The net community production rate was calculated hourly from the change in the dissolved oxygen concentration. The respiration rate was calculated from the linear decrease in dissolved oxygen concentration when PAR $=0 \mu \mathrm{mol}$ photons $\mathrm{m}^{-2} \mathrm{~s}^{-1}$. The hourly mean PAR and the hourly mean seawater temperature were calculated as well. For each month and site, we adjusted a community PI curve to our hourly rates from all replicate chambers by fitting the Jassby and Platt model (Jassby \& Platt 1976) in R software 1.1.442 (R Core Team 2017) together with the phytotools package (Silsbe \& Malkin 2015). We extracted the following parameters from the adjusted curves: efficiency of community production $(\alpha)$ as the slope of the initial curve where irradiance is limited, light saturation point of the community $\left(I_{\mathrm{k}}\right)$ and community respiration $(R)$ as the $y$ intercept when PAR = $0 \mu \mathrm{mol}$ photons $\mathrm{m}^{-2} \mathrm{~s}^{-1}$. Then, we calculated the maximum community production $\left(P_{\max }\right)$ as: 


$$
P_{\max }=\left(\alpha \times I_{\mathrm{k}}\right)-R
$$

while the community compensation irradiance $\left(I_{c}\right)$ was calculated as:

$$
I_{\mathrm{C}}=\frac{(y-R)}{\alpha}
$$

when $y=0$.

\subsection{Data analysis}

The normality of all response variables was analyzed using the Shapiro-Wilk test. One-way ANOVA and post hoc Tukey's HSD tests were conducted to test for significant differences in NCP, $R$, GPP and GPP: $R$ ratio between sites and sampling months. Because of the uneven sampling frequency, we calculated the annual weighted average of all our response variables. Moreover, we tested if the annual weighted average NCP and GPP: $R$ ratio for each site were significantly different from a theoretical value of 0 and 1 , respectively, using $t$-tests to formally assess the autotrophy of both meadows. In addition, we tested the effect of seawater temperature (our continuous explanatory variable) and site (our categorical explanatory variable with 2 levels: monospecific meadow and mixed meadow), as well as their interaction, on NCP, $R$, GPP and GPP: $R$ (our continuous response variables) by linear model $(\mathrm{lm}$, standard least squares) when variables met the assumptions of normal distribution, or by generalized linear model (GLM) when variables were not normally distributed. Differences in $\alpha, I_{\mathrm{k}}, I_{\mathrm{c}}, P_{\max }$ and $R$ between sites were analyzed with and without matching sampling months by using the Wilcoxon signed rank test and the Mann-Whitney test, respectively. The reported values are standardized by area unless stated otherwise. All statistical analyses were conducted in JMP Pro 13.1.0 (SAS Institute) and PRISM (GraphPad Software) statistical software.

\section{RESULTS}

\subsection{In situ seawater temperature, irradiance and biomass}

The range of in situ daily mean seawater temperature was similar in both meadows. The mean in situ seawater temperature varied from $22.8^{\circ} \mathrm{C}$ in February to $33.9^{\circ} \mathrm{C}$ in August in the Cymodocea serrulata and Halodule uninervis mixed meadow and from $22.4^{\circ} \mathrm{C}$ in February to $33.4^{\circ} \mathrm{C}$ in July in the Enhalus acoroides monospecific meadow (Fig. S1 in the Supplement at www.int-res.com/articles/suppl/m614 p079_supp.pdf). While both meadows showed a similar thermal regime, the mixed meadow was exposed to warmer seawater temperatures $\left(>32^{\circ} \mathrm{C}\right)$ over a longer period than the monospecific meadow was. The $C$. serrulata and $H$. uninervis meadow experienced the highest daily mean temperature 1 mo later (August) than the E. acoroides meadow, which was already $2{ }^{\circ} \mathrm{C}$ colder by then. Maximum daily PAR values ranged from 499 to $877.5 \mu \mathrm{mol}$ photons $\mathrm{m}^{-2} \mathrm{~s}^{-1}$ in the mixed meadow, while the monospecific meadow reached maximum daily PAR values of 314.2 to 498 $\mu \mathrm{mol}$ photons $\mathrm{m}^{-2} \mathrm{~s}^{-1}$. Mean above-ground biomass was $839.34 \pm 49.03 \mathrm{~g} \mathrm{DW} \mathrm{m}^{-2}$ in the monospecific meadow and $269.11 \pm 16.97 \mathrm{~g} \mathrm{DW} \mathrm{m}^{-2}$ in the mixed meadow.

\subsection{Net community production}

The NCP of the E. acoroides monospecific meadow was significantly higher than the NCP of the $C$. serrulata and $H$. uninervis mixed meadow over the year, except for February (Table S1 in the Supplement). While the monospecific meadow was net autotrophic during the entire year, the mixed meadow was heterotrophic in September and October (Table 1, Fig. 2). In the monospecific meadow, the highest NCP was detected in July and was significantly higher than the NCP during the winter months (November-April; Fig. 2A). Specifically, the mean $\mathrm{NCP}$ in the monospecific meadow ranged from $34.58 \pm 10.59 \mathrm{mmol} \mathrm{O}_{2} \mathrm{~m}^{-2} \mathrm{~d}^{-1}$ in February to $139.15 \pm 9.67 \mathrm{mmol} \mathrm{O}_{2} \mathrm{~m}^{-2} \mathrm{~d}^{-1}$ in July. The NCP of the mixed meadow was significantly lower in October compared to February-August (Fig. 2B), with the mean NCP ranging from -44.23 $\pm 7.75 \mathrm{mmol} \mathrm{O}_{2} \mathrm{~m}^{-2} \mathrm{~d}^{-1}$ in October to $16.1 \pm 13.93$ mmol $\mathrm{O}_{2} \quad \mathrm{~m}^{-2} \mathrm{~d}^{-1}$ in April. The monospecific meadow was autotrophic during the year, with an annual weighted average NCP $(64.63 \pm 11.89$ $\mathrm{mmol} \mathrm{O}_{2} \mathrm{~m}^{-2} \mathrm{~d}^{-1}$ ) significantly higher than 0 (t-test, $p<0.05)$. On the other hand, the annual weighted average NCP of the mixed meadow $(-4.15 \pm 9.39$ mmol $\mathrm{O}_{2} \mathrm{~m}^{-2} \mathrm{~d}^{-1}$ ) was not significantly different from 0 ( $t$-test, $\mathrm{p}>0.05$ ).

Temperature and site had a significant effect on NCP $\left(\operatorname{lm}\right.$; site $\times$ temperature $\left.F_{1,58}=16.28, \mathrm{p}<0.001\right)$ with a different response depending on the site (Fig. 3A). While the NCP of the monospecific meadow significantly increased with increasing temperature $(\mathrm{p}<0.0001)$, the NCP of the mixed meadow tended to 


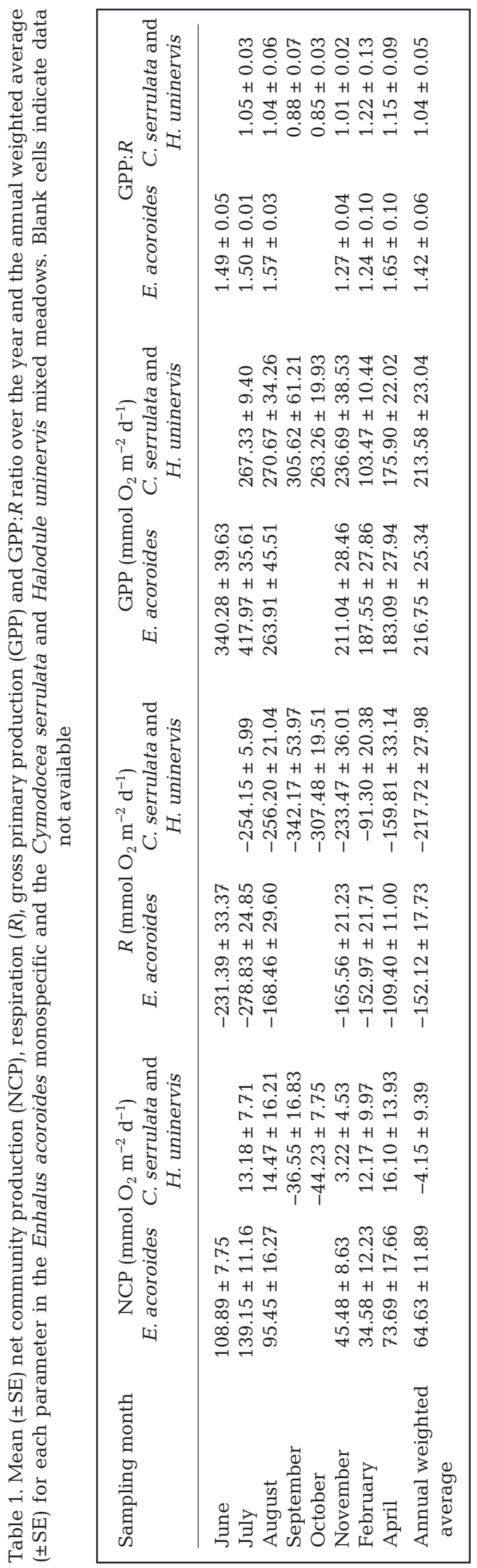

slightly decrease, although the slope was not statistically different from $0(p>0.05)$. In contrast, site and temperature did not have an effect on NPC when standardized by plant biomass. However, the same trend was detected: the NCP of the mixed meadow slightly decreased with increasing temperature $(y=$ $0.006 x+0.16, R^{2}=0.03$ ), and the NCP of the monospecific meadow increased with temperature $\left(\mathrm{GLM}_{\text {; }}\right.$ temperature $\chi_{1,22}^{2}=10.86, p<0.001, y=0.009 x-$ $\left.0.16, \mathrm{R}^{2}=0.37\right)$.

\subsection{Respiration}

In the monospecific meadow, respiration rates peaked in July $\left(-278.83 \pm 24.85 \mathrm{mmol} \mathrm{O}_{2} \mathrm{~m}^{-2} \mathrm{~d}^{-1}\right)$ and were more than 2 -fold higher than respiration rates in the winter months (November-April), reaching the lowest value in April $\left(-109.4 \pm 10.1 \mathrm{mmol} \mathrm{O}_{2} \mathrm{~m}^{-2} \mathrm{~d}^{-1}\right.$; Table 1, Fig. 2A). Respiration rates of the mixed meadow peaked in September $(-342.17 \pm 53.97 \mathrm{mmol}$ $\left.\mathrm{O}_{2} \mathrm{~m}^{-2} \mathrm{~d}^{-1}\right), 2$ mo later than in the monospecific meadow, and were almost 4-fold higher than the lowest value detected in February $(-91.3 \pm 20.38 \mathrm{mmol}$ $\mathrm{O}_{2} \mathrm{~m}^{-2} \mathrm{~d}^{-1}$; Fig. 2B). In August, respiration was significantly higher in the mixed meadow compared to the monospecific meadow (Table S1). The annual weighted average respiration was higher in the mixed meadow with $-217.72 \pm 27.98 \mathrm{mmol} \mathrm{O}_{2} \mathrm{~m}^{-2} \mathrm{~d}^{-1}$ compared to $-152.12 \pm 17.73 \mathrm{mmol} \mathrm{O}_{2} \mathrm{~m}^{-2} \mathrm{~d}^{-1}$ in the monospecific meadow.

Temperature and site had a significant effect on respiration $\left(\mathrm{lm}_{\text {; }}\right.$ temperature $F_{1,58}=28.95, \mathrm{p}<$ 0.0001 ; site $F_{1,58}=4.1, \mathrm{p}<0.05$ ). The magnitude of respiration rates increased linearly with increasing temperature in the monospecific $(p<0.05)$ and mixed ( $<<0.0001)$ meadows (Fig. 3B). The same effect was seen when respiration rates were standardized by plant biomass $\left(\mathrm{GLM}_{i}\right.$ temperature $\chi^{2}{ }_{1,56}=5.0, \mathrm{p}<0.05$; site $\chi_{1,56}^{2}=34.28, \mathrm{p}<0.0001$ ， monospecific meadow: $y=-0.03 x+0.42, \mathrm{R}^{2}=0.22$, mixed meadow: $\left.y=-0.03 x+0.05, R^{2}=0.13\right)$. The associated activation energies of community respiration were $0.32 \pm 0.17$ and $0.87 \pm 0.12 \mathrm{eV}$ for the monospecific and mixed meadows, respectively (Fig. 4A).

\subsection{Gross primary production}

The highest GPP in the monospecific meadow was detected in July $\left(417.97 \pm 35.61 \mathrm{mmol} \mathrm{O}_{2} \mathrm{~m}^{-2} \mathrm{~d}^{-1}\right)$ and was significantly higher than the GPP measured 


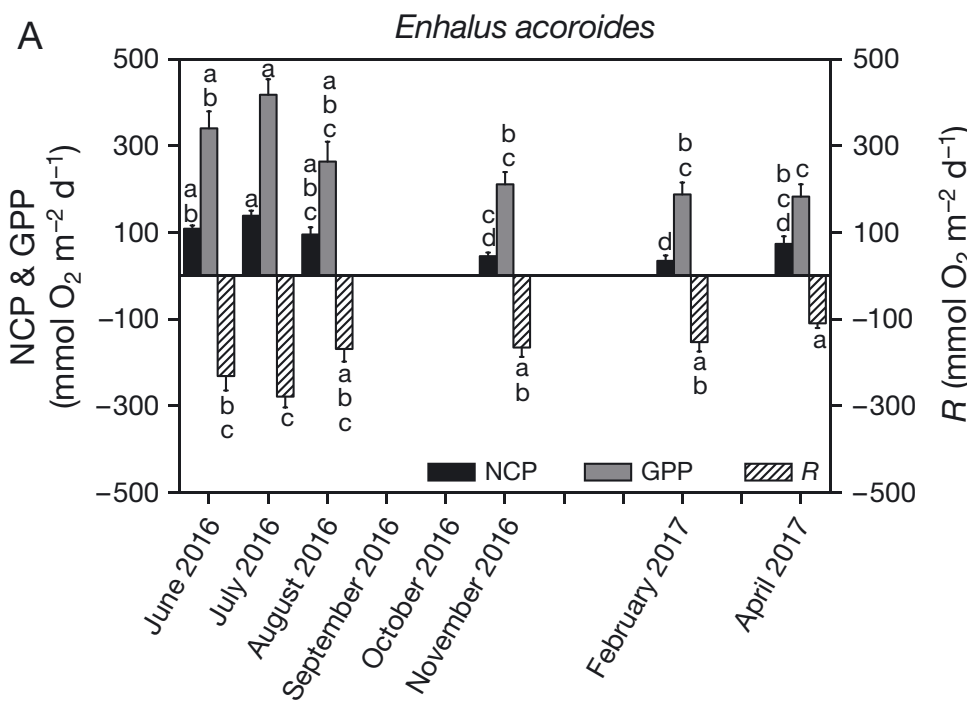

Temperature and site had a significant effect on GPP $\left(\mathrm{lm}_{i}\right.$ temperature $F_{1,58}=37.33, \mathrm{p}$ $<0.0001$; site $F_{1,58}=7.31, \mathrm{p}<0.01$ ). GPP increased linearly with increasing temperature in the monospecific $(p<0.001)$ and mixed ( $p$ $<0.0001$ ) meadows (Fig. 3C). The same trend was seen when GPP was standardized by plant biomass $\left(\mathrm{GLM}\right.$; temperature $\chi_{1,56}^{2}=$ 4.96, $\mathrm{p}<0.05$; site $\chi_{1,56}^{2}=24.74, \mathrm{p}<0.0001$ ， monospecific meadow: $y=0.04 x-0.4, \mathrm{R}^{2}=$ 0.34 , mixed meadow: $y=0.04 x-0.1, R^{2}=$ 0.09 ). The associated activation energies of the community GPP were $0.49 \pm 0.15$ and $0.72 \pm 0.11 \mathrm{eV}$ for the monospecific and mixed meadows, respectively (Fig. 4B).

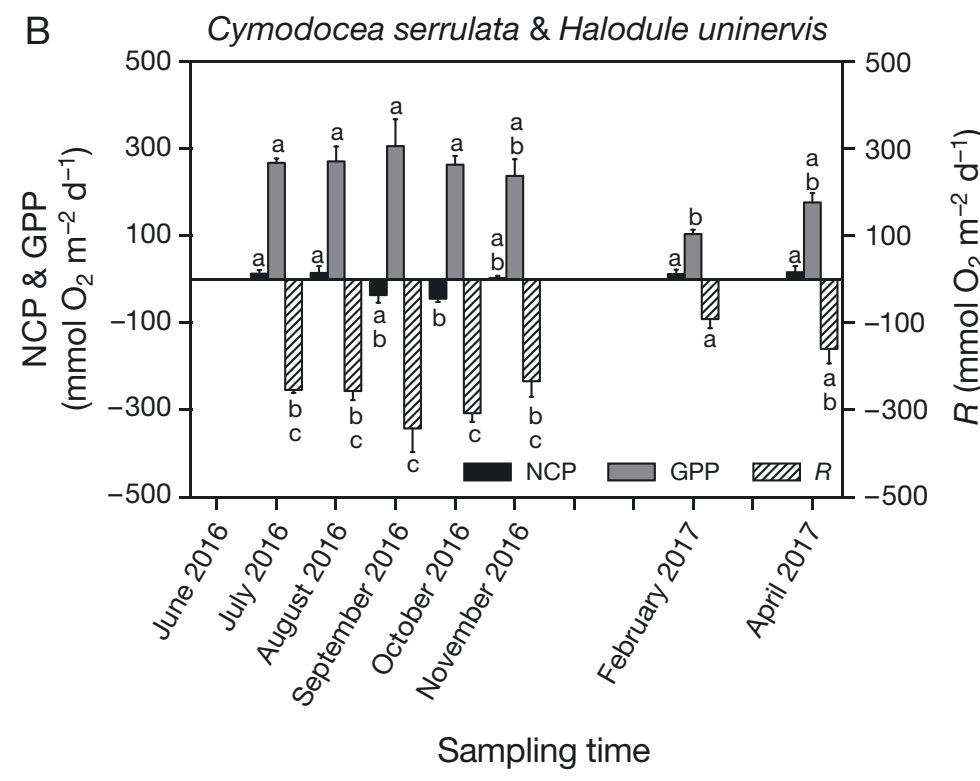

Fig. 2. Mean $( \pm \mathrm{SE})$ net community production $(\mathrm{NCP}$, black $)$, gross primary production (GPP, gray) and respiration $(R$, striped) over the year in the (A) monospecific and (B) mixed meadows. Letters indicate differences among sampling months (ANOVA test)

during the winter months (November-April, Table 1, Fig. 2A). The highest GPP in the mixed meadow was detected in September $\left(305.62 \pm 61.21 \mathrm{mmol} \mathrm{O}_{2}\right.$ $\mathrm{m}^{-2} \mathrm{~d}^{-1}$ ) and was 3-fold higher than the lowest GPP, which was detected in February (103.47 $\pm 10.44 \mathrm{mmol}$ $\mathrm{O}_{2} \mathrm{~m}^{-2} \mathrm{~d}^{-1}$; Fig. 2B). The GPP of the monospecific meadow was significantly higher than the GPP of the mixed meadow in July and February (Table S1). The annual weighted average GPPs were very similar in both sites: $213.58 \pm 23.04$ and $216.75 \pm 25.34 \mathrm{mmol}$ $\mathrm{O}_{2} \mathrm{~m}^{-2} \mathrm{~d}^{-1}$ in the mixed and the monospecific meadows, respectively.

\subsection{GPP: $R$ ratio}

The GPP: $R$ ratio was significantly higher in the monospecific meadow than in the mixed meadow, except for February (Table S1), and it was higher than 1 throughout the year in the monospecific meadow with an annual weighted average ratio of $1.42 \pm 0.06$ (Table 1). The mixed meadow, on the other hand, showed a GPP: $R$ ratio of $<1$ in September and October and had an annual weighted average ratio of $1.04 \pm 0.05$ (Table 1). While the annual weighted average GPP: $R$ ratio in the monospecific meadow was significantly higher than 1 ( $t$-test, $\mathrm{p}<0.05), \mathrm{GPP}: R$ in the mixed meadow was not significantly higher than 1 ( $t$-test, $p>0.05)$. There was an effect of temperature and site on GPP: $R($ GLM; site $\times$ temperature $\left.\chi_{1,55}^{2}=16.4, \mathrm{p}<0.0001\right)$. While GPP: $R$ increased linearly with increasing temperature in the monospecific meadow $\left(\mathrm{GLM}_{i} \chi_{1,22}^{2}=9.41, \mathrm{p}<0.01\right)$, it decreased in the mixed meadow $\left(\mathrm{GLM}_{i} \chi^{2}{ }_{1,33}=6.91, \mathrm{p}<\right.$ 0.01) (Fig. 3D).

\subsection{Community PI curves}

The community production efficiency $(\alpha)$ extracted from the community PI curves (Fig. S2 in the Supplement) ranged from $0.42 \pm 0.17$ to $0.02 \pm 0.01 \mathrm{mmol} \mathrm{O}_{2}$ $\mathrm{h}^{-1}\left(\mu \mathrm{mol} \text { photons s }{ }^{-1}\right)^{-1}$ in September and February, respectively (Table 2). The annual weighted average $\alpha$ was $0.06 \pm 0.03$ and $0.09 \pm 0.04 \mathrm{mmol} \mathrm{O}_{2} \mathrm{~h}^{-1}(\mu \mathrm{mol}$ photons $\left.\mathrm{s}^{-1}\right)^{-1}$ in the monospecific and mixed meadows, respectively, with no significant differences be- 

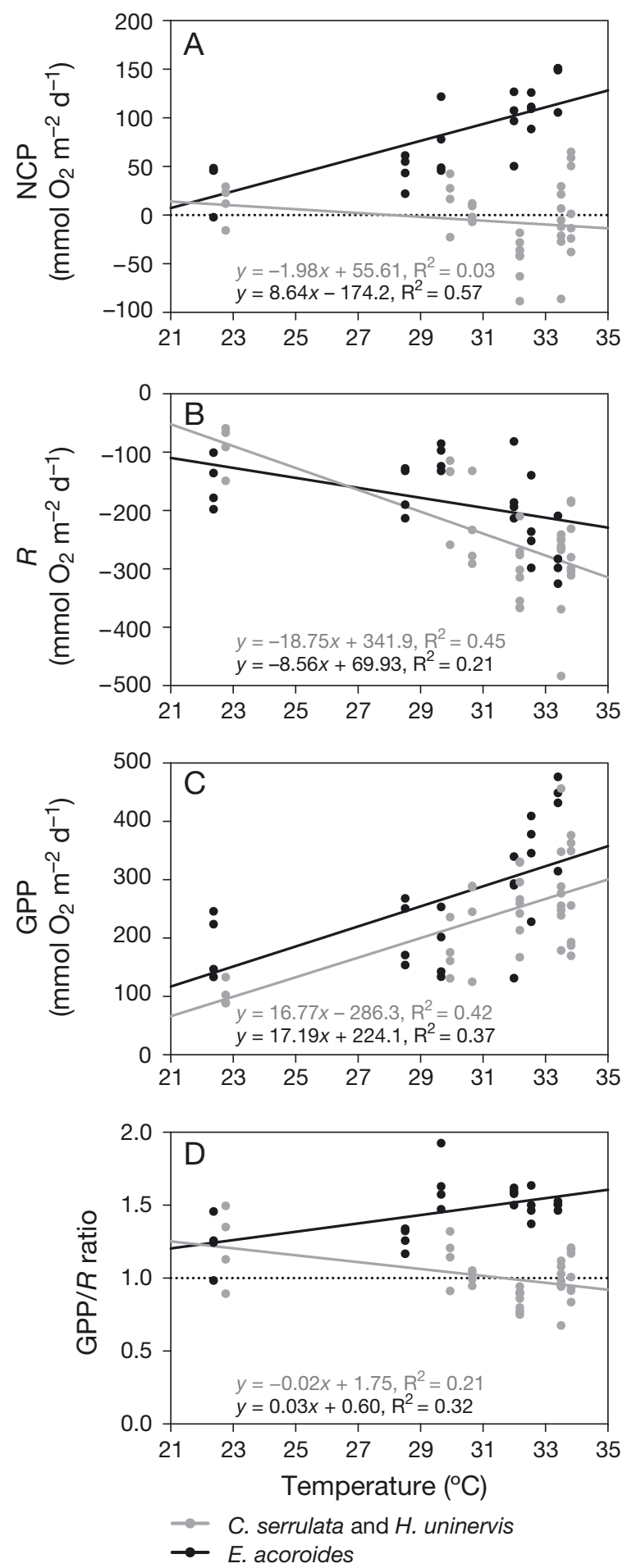

Fig. 3. Relationship of temperature with (A) net community production $(\mathrm{NCP}),(\mathrm{B})$ respiration $(R),(\mathrm{C})$ gross primary production (GPP) and (D) GPP: $R$ ratio in the monospecific (Enhalus acoroides, black dots) and mixed (Cymodocea serrulata and Halodule uninervis, gray dots) meadows. Solid lines indicate the linear regression for the monospecific meadow (black) and the mixed meadow (gray). Dashed lines in (A) and (D) indicate the threshold from autotrophic to heterotrophic communities
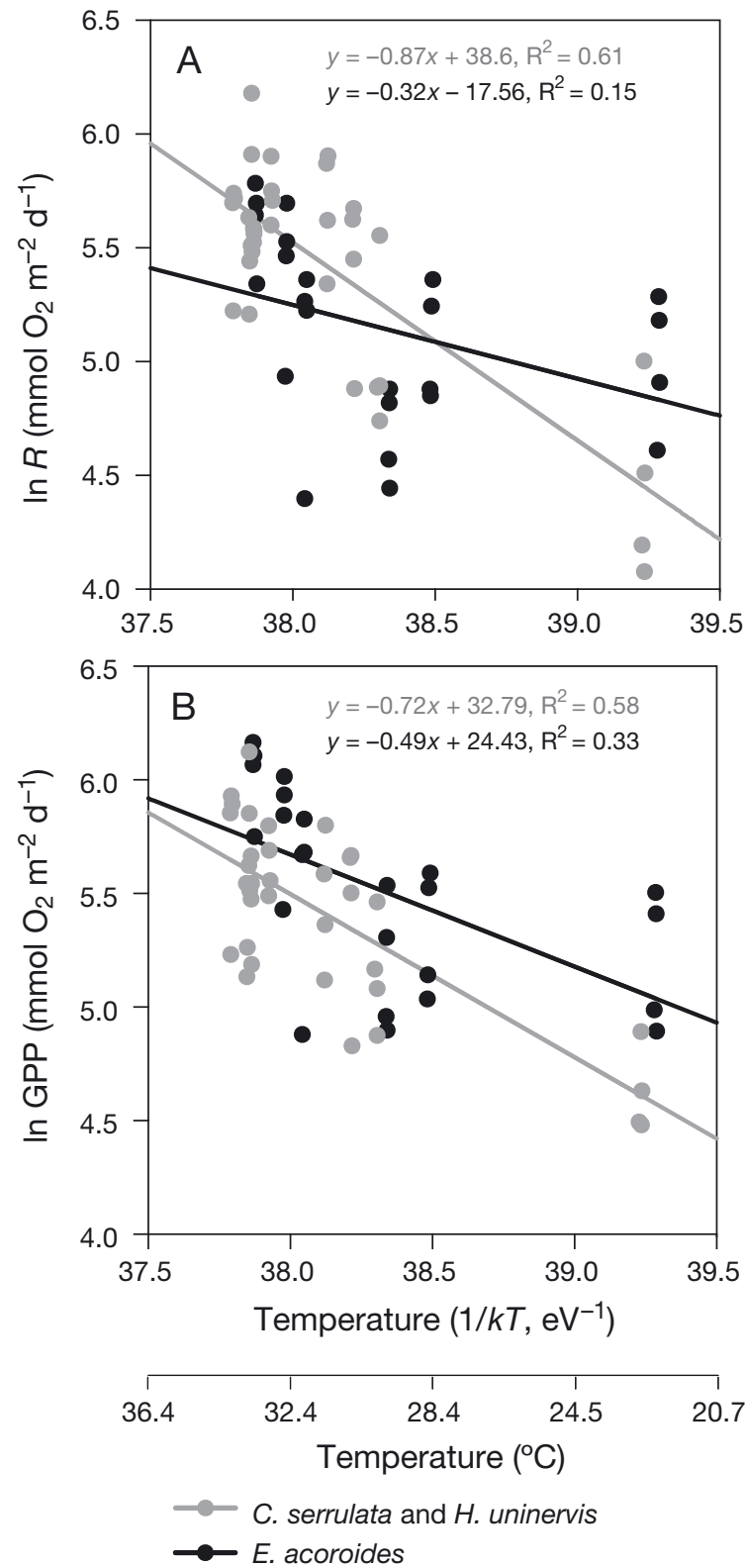

Fig. 4. Arrhenius plots showing the relationship between the inverted temperature multiplied by the Boltzmann constant $(1 / k T)$ and the natural logarithm of $(\mathrm{A})$ respiration $(R)$ and (B) gross primary production (GPP) for the monospecific (black dots) and mixed (gray dots) meadows. Solid lines indicate the linear regression for the monospecific meadow (black) and the mixed meadow (gray). Corresponding temperatures (in ${ }^{\circ} \mathrm{C}$ ) are shown in the lower $x$-axis

tween meadows (Wilcoxon matched-pairs test, $\mathrm{p}>$ 0.05; Mann-Whitney test, $\mathrm{p}>0.05$; Table 2).

The highest $P_{\max }$ in the mixed meadow $(4.62 \mathrm{mmol}$ $\mathrm{O}_{2} \mathrm{~m}^{-2} \mathrm{~h}^{-1}$ ) was reached in August coinciding with the highest temperature, while in the monospecific meadow, the highest $P_{\max }\left(8.17 \mathrm{mmol} \mathrm{O}_{2} \mathrm{~m}^{-2} \mathrm{~h}^{-1}\right)$ was detected in February at the lowest temperature 


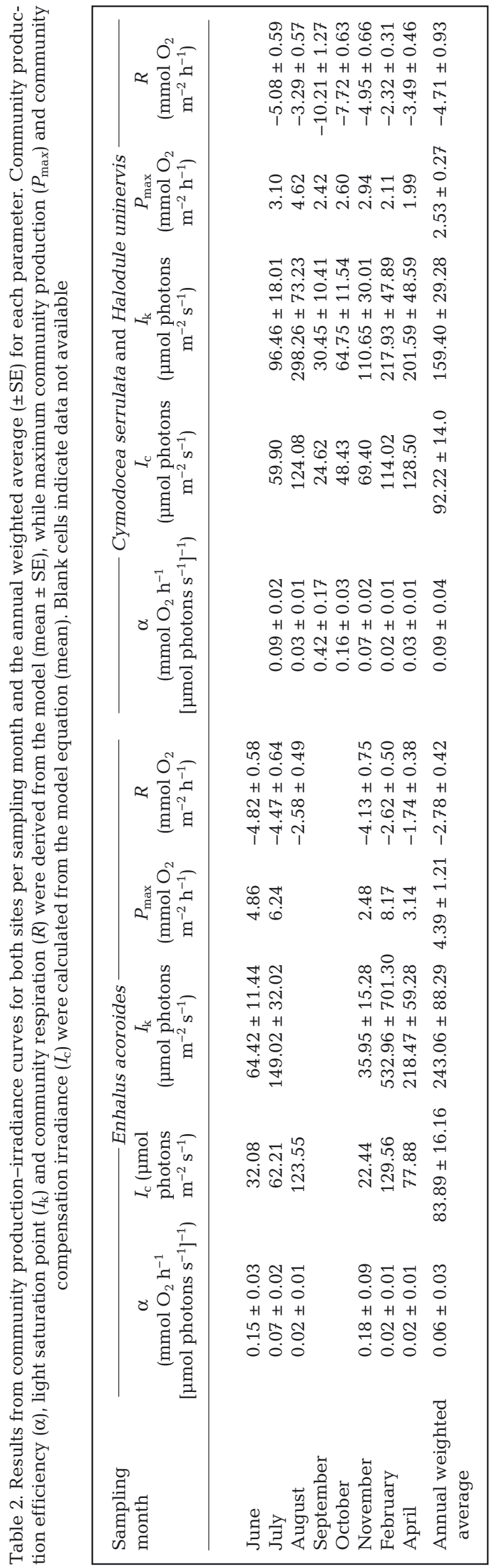

(Table 2, Fig. S2). The annual weighted average $P_{\max }$ was significantly higher in the monospecific meadow than in the mixed meadow $(4.39 \pm 1.21$ and $2.53 \pm$ $0.27 \mathrm{mmol} \mathrm{O}_{2} \mathrm{~m}^{-2} \mathrm{~h}^{-1}$, respectively, Mann-Whitney test, $\mathrm{p}<0.05$ ).

In the monospecific meadow, both $I_{\mathrm{k}}(532.96 \pm$ $701.3 \mu \mathrm{mol}$ photons $\left.\mathrm{m}^{-2} \mathrm{~s}^{-1}\right)$ and $I_{\mathrm{C}}(129.56 \mu \mathrm{mol}$ photons $\mathrm{m}^{-2} \mathrm{~s}^{-1}$ ) were highest in February, while the mixed meadow experienced its highest $I_{\mathrm{k}}(298.26 \pm$ $73.23 \mu \mathrm{mol}$ photons $\mathrm{m}^{-2} \mathrm{~s}^{-1}$ ) in August and its highest $I_{\mathrm{c}}\left(128.5 \mu \mathrm{mol}\right.$ photons $\left.\mathrm{m}^{-2} \mathrm{~s}^{-1}\right)$ in April (Table 2, Fig. S2). The $I_{\mathrm{k}}$ estimate for the monospecific meadow involves considerable error, as indicated by its high standard error, even if an $\mathrm{O}_{2}$ saturation point was clearly reached. The annual weighted average $I_{\mathrm{k}}$ was $243.06 \pm 88.29$ and $159.4 \pm 29.28 \mu \mathrm{mol}$ photons $\mathrm{m}^{-2} \mathrm{~s}^{-1}$ in the monospecific and mixed meadows, respectively, with no significant differences between sites (Wilcoxon matched-pairs test, $\mathrm{p}>0.05$; MannWhitney test, $\mathrm{p}>0.05$ ). The annual weighted average $I_{\mathrm{c}}$ was similar in both sites, with $83.86 \pm 16.16 \mu \mathrm{mol}$ photons $\mathrm{m}^{-2} \mathrm{~s}^{-1}$ in the monospecific meadow and $92.22 \pm 14.0 \mu \mathrm{mol}$ photons $\mathrm{m}^{-2} \mathrm{~s}^{-1}$ in the mixed meadow, with no significant differences (paired $t$-test, $\mathrm{p}>$ 0.05 ; unpaired $t$-test, $\mathrm{p}>0.05$ ).

The monospecific meadow experienced the highest respiration rate in June $\left(-4.82 \pm 0.58 \mathrm{mmol} \mathrm{O}_{2} \mathrm{~m}^{-2}\right.$ $\left.\mathrm{h}^{-1}\right)$ and the lowest in April $\left(-1.74 \pm 0.42 \mathrm{mmol} \mathrm{O}_{2} \mathrm{~m}^{-2}\right.$ $\left.\mathrm{h}^{-1}\right)$. In the mixed meadow, the lowest $R(-2.32 \pm$ $0.31 \mathrm{mmol} \mathrm{O}_{2} \mathrm{~m}^{-2} \mathrm{~h}^{-1}$ ) was detected in February, while the highest $R\left(-10.21 \pm 1.27 \mathrm{mmol} \mathrm{O}_{2} \mathrm{~m}^{-2} \mathrm{~h}^{-1}\right)$ was detected in September (Table 2, Fig. S2). Annual weighted average $R$ values were $-2.78 \pm 0.42$ and $-4.71 \pm 0.93 \mathrm{mmol} \mathrm{O}_{2} \mathrm{~m}^{-2} \mathrm{~h}^{-1}$ in the monospecific and mixed meadows, respectively, with no significant differences between sites (paired $t$-test, $\mathrm{p}>0.05$; unpaired $t$-test, $\mathrm{p}>0.05$ ).

\section{DISCUSSION}

Here we present, for the first time, the metabolic rates and thermal dependence of 2 seagrass ecosystems in the Red Sea, with species-specific results. While the Enhalus acoroides meadow was clearly autotrophic throughout the year, the mixed Cymodocea serrulata and Halodule uninervis meadow was heterotrophic during the summer months. This trend was also confirmed by the mixed meadow having activation energies for both GPP and $R$ twice as high as those of the monospecific meadow, indicating its higher thermal sensitivity compared to the monospecific meadow. These differences in community meta- 
bolism between the 2 meadows can be attributed to multiple factors, such as seagrass biomass density, infauna biomass, epiphyte loads and sediment characteristics, besides the foundation seagrass species. The results presented here were therefore not the sole response of a single seagrass species but represent potential differences in the community composition, including microbial and metazoan components as well as epiphytic algae, of the 2 seagrass meadows studied.

The annual weighted average NCP of the $E$. acoroides meadow in the Red Sea was almost 3-fold greater than the global average rate of $23.7 \pm$ $7.8 \mathrm{mmol} \mathrm{O}_{2} \mathrm{~m}^{-2} \mathrm{~d}^{-1}$ for tropical seagrass meadows (Duarte et al. 2010). A similar trend was stated by Duarte et al. (2010), who noted that the only available record of $E$. acoroides was 5-fold higher than the global average NCP for all seagrass meadows $\left(27.2 \pm 5.8 \mathrm{mmol} \mathrm{O}_{2} \mathrm{~m}^{-2} \mathrm{~d}^{-1}\right)$. In contrast, the annual weighted average NCP of the $C$. serrulata and $H$. uninervis meadow in the Red Sea was considerably lower than the global average. The annual weighted average respiration in the mixed meadow was remarkably similar to the reported global average of tropical seagrass meadows $(-217.48 \pm 13.9 \mathrm{mmol}$ $\mathrm{O}_{2} \mathrm{~m}^{-2} \mathrm{~d}^{-1}$, Duarte et al. 2010), while the annual weighted average respiration was lower in the monospecific meadow. The annual weighted average GPP in both meadows was very similar, yet both rates were slightly lower than the global average of tropical seagrass meadows $\left(252.30 \pm 14.47 \mathrm{mmol} \mathrm{O}_{2} \mathrm{~m}^{-2}\right.$ $\mathrm{d}^{-1}$, Duarte et al. 2010). The difference in respiration was also reflected in the GPP: $R$ ratio, as the mixed meadow, with its higher respiration, consequently had a lower GPP: $R$ ratio, indicating a more balanced state of the ecosystem, while the monospecific meadow was clearly autotrophic. However, the global $P: R$ ratio of tropical seagrass meadows $(1.61 \pm 0.19$; Duarte et al. 2010) was somewhat higher than the ratios reported in this study, particularly for the mixed meadow.

As expected, increasing temperature had significant effects on all metabolic rates, with both $R$ and GPP increasing with warming in both meadows. In contrast, opposite responses were seen in NCP measurements, with NCP increasing with increasing temperature in the E. acoroides meadow and decreasing with increasing temperature in the mixed meadow. Even though these species have shown to be capable of withstanding higher temperatures (Collier et al. 2011, 2017, Adams et al. 2017), our results confirmed that the mixed meadow experienced thermal stress at higher temperatures. However, on a community level, we not only see the response of the foundation seagrass species but can also account for the changes in the metabolism of other primary producers present in the community. We can therefore assume that the $C$. serrulata and $H$. uninervis community had already exceeded its thermal optimum in the Red Sea. When seagrass communities become heterotrophic, they act as $\mathrm{O}_{2}$ sinks, which would favor sulfide production and likely lead to a risk of seagrass mortality (Calleja et al. 2007, Garcias-Bonet et al. 2008). The mixed meadow was exposed to higher temperatures $\left(>32^{\circ} \mathrm{C}\right)$ for an extended period of time, while the temperature in the monospecific meadow was already $2^{\circ} \mathrm{C}$ lower. A negative effect of extended exposure times was also reported for $C$. serrulata and $H$. uninervis (Collier et al. 2018) and for Zostera marina (BecaCarretero et al. 2018). E. acoroides did not seem to be negatively affected during the warmer summer months, suggesting that E. acoroides in the Red Sea had a higher optimal temperature than previously reported, possibly due to local adaptations and acclimation to the conditions in this exceptionally warm sea (Berry \& Bjorkman 1980). Additionally, its large shoot size and the density of the meadow make it more prone to self-shading, which may play a protective role against warm temperatures by reducing exposure to saturating light levels at which photosynthesis is particularly impacted by high temperature (Pedersen et al. 2013). While we saw mixed responses, Egea et al. (2019) reported a positive effect of increased seawater temperature on a C. nodosa meadow in southern Spain, indicating that this community was still well below its thermal optimum. They reported the meadow to be more autotrophic when exposed to short-term heatwaves, highlighting a potential positive effect of elevated temperatures on healthy seagrass meadows below their thermal limit (Egea et al. 2019).

The thermal dependence of these 2 meadows confirmed the overall trend in this study. Generally, the monospecific meadow had lower activation energies, indicating that the metabolism of the mixed meadow was more sensitive to temperature. The monospecific meadow had a higher activation energy for GPP than for $R$. Beca-Carretero et al. (2018) reported a similar trend in $Z$. marina, with activation energies of leaf respiration (0.27-0.46 eV) and rhizome respiration (0.53-0.67 eV) lower than their results for $P_{\max }(0.77-$ $0.99 \mathrm{eV})$. In contrast, the mixed meadow had a higher activation energy for $R$ compared to GPP, albeit none of these differences were statistically significant, explaining the lower GPP: $R$ ratio at higher temperatures in summer and the overall lower GPP: $R$ ratio 
compared to the monospecific meadow (RegaudieDe-Gioux \& Duarte 2012). Our results therefore confirmed that the mixed meadow was more sensitive to higher temperatures and was more likely to shift to a heterotrophic state with warming.

Contrary to our expectations and previous results, the monospecific meadow did not show PI curve characteristics of a shade-adapted species. Shadeadapted species compensate for lower light availability by exhibiting lower $I_{\mathrm{k}}$ values (Campbell et al. 2007). Even though E. acoroides is more likely to be shade-adapted because of its size and the density of the meadow, neither the higher $I_{\mathrm{k}}$ nor the lower photosynthetic efficiency compared to the mixed meadow indicated an adaptation at the community level (Larkum et al. 2006). However, the highest $\alpha$ coincided with the lowest $I_{\mathrm{k}}$ and the lowest $I_{\mathrm{c}}$ in both meadows, confirming a photoadaptive response of both meadows to being more efficient at low light levels (Campbell et al. 2007). Georgiou et al. (2016) reported an increasing photosynthetic efficiency with increasing temperature for Halophila stipulacea in the Mediterranean, while Pollard \& Greenway (2013) found the same trend for C. serrulata in Australia. However, this trend could not be confirmed in our study, as we saw mixed responses throughout the year.

Both $P_{\max }$ and $R$ were generally higher during the warmer summer months, confirming the expectation that both parameters increase with increasing temperature (Georgiou et al. 2016), with high $P_{\max }$ values at higher temperatures indicating a response mechanism to compensate for higher respiration rates caused by higher temperatures (Pollard \& Greenway 2013). While $R$ was highest in summer in both meadows, the elevated response was higher in the mixed meadow (5-fold) compared to the monospecific meadow (3-fold), confirming the general trend that it is more sensitive to temperature (Pollard \& Greenway 2013).

In summary, our results suggest a species-specific response of seagrass meadows to increasing seawater temperatures in the Red Sea. On the one hand, the monospecific $E$. acoroides meadow did not show signs of thermal stress, seemed to be well below its thermal optimum and showed relatively low activation energy for community metabolism. On the other hand, in the mixed C. serrulata and H. uninervis meadow, the community metabolism increased steeply with increasing temperature and shifted to a heterotrophic state at higher temperatures, turning the meadow into a carbon source rather than a carbon sink. It can therefore be implied that some seagrass species in the Red Sea, even though they are expected to be adapted to higher temperatures, grow close to or already exceed their thermal optima during the warmest period of the year. The steep warming that the Red Sea is experiencing is likely to pose serious challenges to the more vulnerable species, such as those in the mixed seagrass meadow studied here. These results confirm that some seagrasses in the Red Sea are thermally stressed, which may have important implications for the future of the essential ecosystem functions and services seagrass ecosystems perform in the Red Sea.

Acknowledgments. This research was funded by King Abdullah University of Science and Technology through baseline funding to C.M.D. C.B. was supported by King Abdullah University of Science and Technology through the Visiting Student Research Program. We thank Marco Fusi, Janna Leigh Randle and the crew at CMOR for their support during fieldwork. We thank Ute Langner for creating the maps and Greg Silsbe for his help and advice on the PI models in the phytotools package.

\section{LITERATURE CITED}

Adams MP, Collier CJ, Uthicke S, Ow YX, Langlois L, O'Brien KR (2017) Model fit versus biological relevance: evaluating photosynthesis-temperature models for three tropical seagrass species. Sci Rep 7:39930

Arias-Ortiz A, Serrano O, Masqué P, Lavery PS and others (2018) A marine heatwave drives massive losses from the world's largest seagrass carbon stocks. Nat Clim Chang 8:338-344

*Beca-Carretero P, Olesen B, Marbà N, Krause-Jensen D (2018) Response to experimental warming in northern eelgrass populations: comparison across a range of temperature adaptations. Mar Ecol Prog Ser 589:59-72

Belkin IM (2009) Rapid warming of large marine ecosystems. Prog Oceanogr 81:207-213

* Berry J, Bjorkman O (1980) Photosynthetic response and adaptation to temperature in higher plants. Annu Rev Plant Physiol 31:491-543

Brown JH, Gillooly JF, Allen AP, Savage VM, West GB (2004) Toward a metabolic theory of ecology. Ecology 85: 1771-1789

Bulthuis DA (1987) Effects of temperature on photosynthesis and growth of seagrasses. Aquat Bot 27:27-40

Calleja ML, Marbà N, Duarte CM (2007) The relationship between seagrass (Posidonia oceanica) decline and sulfide porewater concentration in carbonate sediments. Estuar Coast Shelf Sci 73:583-588

Campbell SJ, McKenzie LJ, Kerville SP, Bité JS (2007) Patterns in tropical seagrass photosynthesis in relation to light, depth and habitat. Estuar Coast Shelf Sci 73:551-562

Carlson DF, Yarbro LA, Scolaro S, Poniatowski M, McGeeAbsten V, Carlson PR (2018) Sea surface temperatures and seagrass mortality in Florida Bay: spatial and temporal patterns discerned from MODIS and AVHRR data. Remote Sens Environ 208:171-188

Chaidez V, Dreano D, Agusti S, Duarte CM, Hoteit I (2017) Decadal trends in Red Sea maximum surface temperature. Sci Rep 7:8144 
Collier CJ, Waycott M (2014) Temperature extremes reduce seagrass growth and induce mortality. Mar Pollut Bull 83: 483-490

Collier CJ, Uthicke S, Waycott M (2011) Thermal tolerance of two seagrass species at contrasting light levels: implications for future distribution in the Great Barrier Reef. Limnol Oceanogr 56:2200-2210

Collier CJ, Ow YX, Langlois L, Uthicke S and others (2017) Optimum temperatures for net primary productivity of three tropical seagrass species. Front Plant Sci 8:1446

* Collier CJ, Langlois L, Ow Y, Johansson C and others (2018) Losing a winner: thermal stress and local pressures outweigh the positive effects of ocean acidification for tropical seagrasses. New Phytol 219:1005-1017

Collins M, Knutti R, Arblaster J, Dufresne JL and others (2013) Long-term climate change: projections, commitments and irreversibility. In: Stocker TF, Qin D, Plattner GK, Tignor M and others (eds) Climate change 2013: the physical science basis. Contribution of Working Group I to the Fifth Assessment Report of the Intergovernmental Panel on Climate Change. Cambridge University Press, Cambridge, p 1029-1136

* Costanza R, D'Arge R, de Groot R, Farber S and others (1997) The value of the world's ecosystem services and natural capital. Nature 387:253-260

Dell AI, Pawar S, Savage VM (2011) Systematic variation in the temperature dependence of physiological and ecological traits. Proc Natl Acad Sci USA 108:10591-10596

Díaz-Almela E, Marbà N, Martínez R, Santiago R, Duarte CM (2009) Seasonal dynamics of Posidonia oceanica in Magalluf Bay (Mallorca, Spain): temperature effects on seagrass mortality. Limnol Oceanogr 54:2170-2182

* Duarte CM, Chiscano CL (1999) Seagrass biomass and production: a reassessment. Aquat Bot 65:159-174

* Duarte CM, Marbà N, Gacia E, Fourqurean JW, Beggins J, Barrón C, Apostolaki ET (2010) Seagrass community metabolism: assessing the carbon sink capacity of seagrass meadows. Global Biogeochem Cycles 24:GB4032

Duarte CM, Agusti S, Regaudie-de-Gioux A (2011) The role of marine biota in the biogeochemical and geological cycles of carbon. In: Duarte CM (ed) The role of marine biota in the functioning of the biosphere. Fundación BBVA, Madrid, p 39-54

Egea LG, Jiménez-Ramos R, Hernández I, Brun FG (2019) Effect of in situ short-term temperature increase on carbon metabolism and dissolved organic carbon (DOC) fluxes in a community dominated by the seagrass $C y m o-$ docea nodosa. PLOS ONE 14:e0210386

* Garcias-Bonet N, Marbà N, Holmer M, Duarte CM (2008) Effects of sediment sulfides on seagrass Posidonia oceanica meristematic activity. Mar Ecol Prog Ser 372:1-6

* Georgiou D, Alexandre A, Luis J, Santos R (2016) Temperature is not a limiting factor for the expansion of Halophila stipulacea throughout the Mediterranean Sea. Mar Ecol Prog Ser 544:159-167

Green EP, Short FT (2003) World atlas of seagrasses. University of California Press, Berkeley, CA

*Harris LA, Duarte CM, Nixon SW (2006) Allometric laws and prediction in estuarine and coastal ecology. Estuaries Coasts 29:340-344

Jassby AD, Platt T (1976) Mathematical formulation of the relationship between photosynthesis and light for phytoplankton. Limnol Oceanogr 21:540-547

Krause-Jensen D, Serrano O, Apostolaki ET, Gregory DJ, Duarte CM (2019) Seagrass sedimentary deposits as security vaults and time capsules of the human past. Ambio 48:325-335

Lamb JB, van de Water JAJM, Bourne DG, Altier C and others (2017) Seagrass ecosystems reduce exposure to bacterial pathogens of humans, fishes, and invertebrates. Science 355:731-733

Larkum AWD, Drew E, Ralph PJ (2006) Photosynthesis in seagrasses. In: Larkum AWD, Orth RJ, Duarte CM (eds) Seagrass biology, ecology and conservation. Springer, Dordrecht, p 323-345

Lee KS, Park SR, Kim YK (2007) Effects of irradiance, temperature, and nutrients on growth dynamics of seagrasses: a review. J Exp Mar Biol Ecol 350:144-175

* Marbà N, Duarte CM (2010) Mediterranean warming triggers seagrass (Posidonia oceanica) shoot mortality. Glob Change Biol 16:2366-2375

Marbà N, Jordà G, Agustí S, Girard C, Duarte CM (2015) Footprints of climate change on Mediterranean Sea biota. Front Mar Sci 2:1-11

Marsh JA Jr, Dennison WC, Alberte RS (1986) Effects of temperature on photosynthesis and respiration in eelgrass (Zostera marina L.). J Exp Mar Bio Ecol 101: 257-267

* Masini RJ, Cary JL, Simpson CJ, McComb AJ (1995) Effects of light and temperature on the photosynthesis of temperate meadow-forming seagrasses in Western Australia. Aquat Bot 49:239-254

Moore KA, Jarvis JC (2008) Eelgrass diebacks in the lower Chesapeake Bay : implications for long-term persistence. J Coast Res 55(Spec Issue):135-147

* Moore KA, Shields EC, Parrish DB (2014) Impacts of varying estuarine temperature and light conditions on Zostera marina (eelgrass) and its interactions with Ruppia maritima (widgeongrass). Estuaries Coasts 37:20-30

* Orth RJ, Carruthers TJB, Dennison WC, Duarte CM and others (2006) A global crisis for seagrass ecosystems. Bioscience 56:987-996

Pedersen MØ, Serrano O, Mateo MÁ, Holmer M (2011) Temperature effects on decomposition of a Posidonia oceanica mat. Aquat Microb Ecol 65:169-182

* Pedersen O, Colmer TD, Sand-Jensen K (2013) Underwater photosynthesis of submerged plants-recent advances and methods. Front Plant Sci 4:140

Pedersen O, Colmer TD, Borum J, Zavala-Perez A, Kendrick GA (2016) Heat stress of two tropical seagrass species during low tides - impact on underwater net photosynthesis, dark respiration and diel in situ internal aeration. New Phytol 210:1207-1218

* Pollard PC, Greenway M (2013) Seagrasses in tropical Australia, productive and abundant for decades decimated overnight. J Biosci 38:157-166

R Core Team (2017) R: a language and environment for statistical computing. R Foundation for Statistical Computing, Vienna

* Regaudie-De-Gioux A, Duarte CM (2012) Temperature dependence of planktonic metabolism in the ocean. Global Biogeochem Cycles 26:GB1015

* Ruiz-Frau A, Gelcich S, Hendriks IE, Duarte CM, Marbà N (2017) Current state of seagrass ecosystem services: research and policy integration. Ocean Coast Manage 149:107-115

Short FT, Neckles HA (1999) The effects of global climate change on seagrasses. Aquat Bot 63:169-196

Silsbe G, Malkin SY (2015) Phytotools: phytoplankton production tools https://cran.r-project.org/web/packages/ phytotools/index.html

York PH, Gruber RK, Hill R, Ralph PJ, Booth DJ, Macreadie PI (2013) Physiological and morphological responses of the temperate seagrass Zostera muelleri to multiple stressors: investigating the interactive effects of light and temperature. PLOS ONE 8:e76377 